\title{
KEEFEKTIFAN PENGGUNAAN MEDIA POSTER DAN MIND MAPPING DALAM PEMBELAJARAN KETERAMPILAN BERPIDATO SISWA SMK
}

\author{
Wirayudha Pramana Bhakti ${ }^{1)}$, Haryadi ${ }^{2)}$ \\ Program Studi Lingustik Terapan PPs UNY ${ }^{1)}$, Universitas Negeri Yogyakarta ${ }^{2)}$ \\ yudha_lia15@yahoo.com ${ }^{1)}$,prof_haryadi@yahoo.co.id ${ }^{2)}$
}

\begin{abstract}
Abstrak
Tujuan penelitian ini yaitu untuk mengidentifikasi (1) perbedaan keefektifan antara penggunaan media mind mapping dengan pembelajaran tanpa media dalam pembelajaran keterampilan berpidato siswa SMK, (2) perbedaan keefektifan antara penggunaan media poster dengan pembelajaran tanpa media dalam pembelajaran keterampilan berpidato siswa SMK, serta (3) perbedaan keefektifan penggunaan media poster dengan media mind mapping dalam pembelajaran keterampilan berpidato siswa SMK. Desain eksperimen yang digunakan adalah Randomized Pretest-Postest Control Group Design, dengan dua kelompok eksperimen dan satu kelompok kontrol. Populasi penelitian ini adalah seluruh peserta didik kelas X jurusan otomotif SMK Diponegoro Depok, Sleman, Yogyakarta. Penentuan kelompok kontrol dan eksperimen dilakukan secara random. Pengumpulan data penenelitian melalui lembar penilaian performansi keterampilan berpidato. Instrumen divalidasi dengan uji validitas isi yang melibatkan expert judgment. Data dianalisis dengan Anava dilanjutkan dengan uji Scheffe. Hasil penelitian menunjukkan bahwa (1) media mind mapping lebih efektif dibandingkan pembelajaran tanpa media pembelajaran, (2) media poster lebih efektif dibandingkan pembelajaran tanpa media pembelajaran, (3) media mind mapping merupakan media yang paling efektif dibandingkan dengan media poster dan pembelajaran tanpa media.
\end{abstract}

Kata Kunci: keefektifan, pembelajaran, poster, mind mapping, berpidato

\section{THE EFFECTIVENESS OF POSTER AND MIND MAPPING MEDIA IN THE LEARNING OF SPEECH OF VOCATIONAL SCHOOL STUDENT}

\begin{abstract}
The purpose of the study was to describe (1) the difference between the effectiveness of media use mind mapping to learning without the media in addressing student learning vocational skills, (2) the difference between the effectiveness of the use of instructional media poster with no media in addressing student learning vocational skills, as well as (3) differences in the effectiveness of the use of media by media mind mapping posters in learning speech skills of vocational students. Experimental design used was a randomized pretest-posttest control group design, with two experimental groups and one control group. The study population was all class $X$ students majoring in automotive SMK Diponegoro Depok, Sleman, Yogyakarta. Determination of the control and experimental groups conducted randomly. The investigations of data collection through performance assessment form speech skills. Validated instrument with content validity test involving expert judgment. Data were analyzed by ANOVA followed by Scheffe test. The results showed that (1) media mind mapping is more effective than learning without learning media, (2) medium poster is more effective than learning without learning media, (3) media mind mapping is the most effective media compared to media without posters and instructional media.
\end{abstract}

Keywords: effectiveness, learning, poster, mind mapping, speech 


\section{PENDAHULUAN}

Kegiatan bertutur atau berbicara mempunyai kedudukan dan fungsi yang penting sekali dalam kehidupan manusia bermasyarakat dan berbudaya. Pertama, kegiatan ini secara khas menandai kehadiran corak hidup manusia serta membedakannya dengan corak hidup makluk-makluk lainnya. Kedua, dengan bertutur manusia dapat berinteraksi, mengungkapkan dirinya, pengetahuannya, dan lingkungan sekitarnya. Ketiga, kegiatan bertutur dapat dilihat dalam perkembangan ilmu pengetahuan. Salah satu kegiatan bertutur yaitu berpidato (Oka, 1976, pp.1-2).

Kemampuan berpidato penting bagi siswa, sebab pidato merupakan cara yang baik untuk membantu berkomunikasi dan berinteraksi. Pidato juga merupakan sarana menyampaikan gagasan yang penting secara lisan dengan khalayak umum. Oleh sebab itu, kemampuan berpidato masuk dalam materi pembelajaran bahasa Indonesia di SMK. Dewasa ini, siswa SMK dituntut cerdas dan terampil khususnya pada bidang kejuruannya serta tak terkecuali pada bidang bahasa, yaitu kemampuan berbicara (berpidato), kemampuan berbahasa tersebut diharapkan dapat menunjang kompetensi siswa di bidang kejuruannya. Akan tetapi, kecenderungan pembelajaran berpidato khususnya di SMK dilaksanakan secara konvensional tanpa menggunakan media pembelajaran.

Penggunaan media pembelajaran pada dasarnya bertujuan mempertinggi proses belajar siswa yang pada akhirnya diharapkan dapat mempertinggi hasil belajar dan kompetensi yang ingin dicapai. Peranan media pembelajaran bukan hanya sebagai sumber informasi tetapi dapat dimanfaatkan untuk membantu siswa dalam meningkatkan kompetensi berbahasa, dalam hal ini kompetensi berbicara khususnya kemampuan berpidato. Media pembelajaran juga dapat memungkinkan siswa menguasai tujuan pembelajaran dengan baik dan dapat menumbuhkan kreativitas serta motivasi siswa dalam belajar.

Beberapa contoh media pembelajaran yang sesuai digunakan dalam pembelajaran berpidato di SMK yaitu poster dan mind mapping. Sesuai dengan pidato, poster juga merupakan salah satu bentuk komunikasi dan interaksi dengan publik. Dalam poster dan pidato juga terdapat pesan yang ingin disampaikan kepada publik, hanya saja poster berupa gambar dan tulisan berbeda dengan pidato yang berupa lisan. Poster sendiri juga relatif murah serta mudah dicari dan ditemukan, akan tetapi media yang mudah dan murah tersebut tersebut belum pernah digunakan sebagai media pembelajaran dalam berpidato terutama di SMK. Padahal penggunaan media tersebut diharapkan dapat meningkatkan kemampuan siswa dalam berpidato. Media poster dapat membantu memperkuat gagasan dan ide siswa SMK dalam menyampaikan pidato serta diharapkan memotivasi dan memancing ide-ide kreatif siswa SMK dalam berpidato. Ide dalam poster yang berupa gambar penuh warna serta tulisan singkat padat namun menarik dapat menumbuhkan daya kreatif dan motivasi siswa dalam belajar menyampaikan pidato baik segi cara maupun isinya.

Selain poster, media pembelajaran yang dapat digunakan dalam proses pembelajaran pidato siswa SMK yaitu mind mapping. Salah satu ciri berpidato yang baik yaitu pidato yang terkonsep secara jelas dan runtut. Sesuai dengan hal tersebut maka media pembelajaran yang juga dapat digunakan dalam pembelajaran berpidato di SMK yaitu peta konsep atau mind mapping. Bagi siswa SMK peta konsep atau mind mapping merupakan hal yang tidak asing lagi. Misalnya di SMK bidang keahlian mesin atau otomotif, peta konsep sering dipakai untuk memetakan bagian mesin-mesin industri serta kendaraan bermotor. Mind mapping di SMK juga sering digunakan untuk mengkonsep dan mengurutkan proses pembongkaran mesin atau servis kendaraan bermotor pada proses pembelajaran praktik otomotif. Walaupun mudah ditemui, mind mapping tersebut sangat jarang digunakan dalam pembelajaran bahasa Indonesia, terutama pembelajaran berpidato bagi siswa SMK. Padahal dengan peta konsep atau mind mapping diharapkan dapat membantu siswa untuk mengkonsep ide-ide kreatif mereka dan membantu siswa dalam berpidato secara runtut dan jelas. Dengan demikian, kemampuan berpidato siswa SMK dapat meningkat.

Permasalahan dalam penelitian ini yaitu belum diketahuinya keefektifan penggunaan media mind mapping dan poster serta belum diketahui media mana yang lebih efektif diantara kedua media tersebut dalam pembelajaran keterampilan berpidato siswa SMK. Tujuan dalam penelitian ini yaitu untuk mengidentifikasi (1) perbedaan keefektifan antara penggunaan media mind mapping dengan pembelajaran tanpa media dalam pembelajaran keterampilan berpidato siswa SMK, (2) perbedaan keefektifan antara penggunaan media poster dengan pem- 
belajaran tanpa media dalam pembelajaran keterampilan berpidato siswa SMK, serta (3) perbedaan keefektifan penggunaan media poster dengan media mind mapping dalam pembelajaran keterampilan berpidato siswa SMK.

Buzan (2008, pp.4-6), berpendapat bahwa mind mapping merupakan alat paling hebat yang membantu otak untuk berpikir secara teratur. Mind mapping juga merupakan salah satu cara yang paling mudah untuk memasukkan informasi ke dalam otak, dan untuk mengambil informasi dari otak. Mind mapping atau peta konsep dapat didefinisikan sebagai salah satu metode yang membantu memudahkan siswa untuk berpikir secara teratur dan terkonsep dalam belajar yang berwujud media pembelajaran yang di dalamnya terdapat ilustrasi grafis konkret berupa gambar dan tulisan dua dimensi yang digunakan siswa dalam pembelajaran keterampilan berpidato agar siswa dalam berpidato di depan kelas agar pidato menjadi runtut, jelas serta terkonsep dengan baik dan benar.

Rivai \& Sudjana (2002, p.51), menyatakan bahwa poster merupakan salah satu media pembelajaran visual dapat didefinisikan sebagai kombinasi visual dari rancangan yang kuat dengan warna dan pesan dengan maksud untuk menangkap perhatian orang yang lewat tetapi cukup lama menanamkan gagasan yang berarti dalam ingatannnya. Peranannnya sangat cepat dalam menanamkan atau mengingatkan kembali kepada para pengamat pada satu gagasan pentingnya. Poster dapat diwujudkan menjadi sebuah media pembelajaran yang digunakan siswa dalam pembelajaran keterampilan berpidato agar siswa pidato dalam berpidato di depan kelas menjadi lebih kreatif, jelas serta bermakna.

Pengertian pidato menurut Hadinegoro (2007, p.1), adalah pengungkapan pikiran dalam bentuk kata-kata yang ditujukan kepada orang banyak, atau wacana yang disisipkan untuk diucapkan di depan khalayak, dengan maksud agar para pendengar dari pidato tadi dapat mengetahui, memahami, menerima serta diharapkan bersedia melaksanakan segala sesuatu yang disampaikan terhadap mereka. Keterampilan berpidato adalah suatu keterampilan yang dimiliki siswa untuk mengungkapkan ide atau pikiran yang ditujukan untuk orang lain secara lisan di depan kelas yang berupa nilai tes unjuk kerja bahasa yang diambil dari penilaian tes performansi berpidato siswa dengan menggunakan suatu perangkat evaluasi pembelajaran berupa rubrik penilaian performansi keterampilan berpidato.

\section{METODE}

\section{Jenis Penelitian}

Penelitian ini merupakan penelitian kuantitatif dengan pendekatan eksperimen semu (quasi experimental). Desain eksperimental yang digunakan dalam penelitian ini adalah Randomized Pretest-Posttest Control Group Design (Campbell \& Stanley, 1996, p.13). Desain penelitian tersebut merupakan suatu desain penelitian eksperimen dengan menggunakan dua kelompok, yaitu kelompok kontrol dan kelompok eksperimen yang diawali dengan pretes dan diakhiri dengan postes. Pembelajaran ini melibatkan 3 variabel bebas, media poster (X1), media mind mapping (X2), dan pembelajaran tanpa menggunakan media (X3). Variabel terikatnya adalah kemampuan berpidato (Y).

\section{Waktu dan Tempat Penelitian}

Penelitian ini dilakukan di SMK Diponegoro Depok, Sleman (SMK Binaan FT UNY) pada bulan Juli-September 2012 atau pada awal semester 1/gasal tahun ajaran 2012/2013 sebanyak 6 kali pertemuan di setiap kelas.

\section{Populasi dan Sampel Penelitian}

Populasi dalam penelitian ini seluruh peserta didik kelas $\mathrm{X}$ jurusan Teknik Otomotif di SMK Diponegoro, Depok, Sleman. Jumlah populasi dalam penelitian ini 88 siswa. Penentuan kelompok kontrol dan kelompok eksperimen dilakukan secara random melalui undian. Masing-masing kelas diambil 20 siswa secara acak,sehingga dari 3 kelas didapat sampel berjumlah 60 siswa.

\section{Prosedur Eksperimen}

Sebelum eksperimen, dilakukan terle-bih dahulu pra-eksperimen yang mencakup beberapa kegiatan, yaitu pelatihan guru pelaksana eksperimen, menyiapkan bahan pembelajaran kemudian menentukan sampel penelitian. Selanjutnya, dilaksanakan ekperimen sebanyak enam kali pertemuan pada setiap kelas eksperimen dan kelas kontrol yang mencakup beberapa kegiatan yaitu pretes, perlakuan dan postes.

\section{Teknik Pengumpulan Data}

Pengumpulan data penelitian ini dilakukan dengan mengamati performansi keterampilan berpidato peserta didik dengan panduan lembar pengamatan dan lembar penilaian performansi kompetensi berbicara khususnya keterampilan berpidato. Penilaian performansi dila- 
kukan 2 kali, yaitu sebelum perlakuan dan sesudah perlakuan.

\section{Instrumen Pengumpulan Data}

Pengambilan data dalam penelitian ini menggunakan instrumen lembar penilaian performansi keterampilan berpidato. Instrumen tersebut dibuat menggunakan skala Likert dengan 5 alternatif tingkatan (5:sangat baik, 4:baik, 3:sedang, 2:kurang, dan 1:kurang sekali). Instrumen tersebut berdasarkan pada teori pedoman penilaian keterampilan berbicara menurut Brown (2004, pp.172-173), yaitu tata bahasa, kosakata, pemahaman, kefasihan, pengucapan, dan tugas. Dengan demikian, dihasilkan lembar penilaian performansi keterampilan berpidato yang meliputi ketepatan informasi, keruntutan penyampaian gagasan, ketepatan penggunaan bahasa, ketepatan gaya/stile penuturan, serta kelancaran dan kewajaran penuturan.

\section{Teknik Analisis Data}

Teknik analisis data yang digunakan dalam penelitian ini adalah teknik statistik parametrik yaitu Anava atau Analysis of Variance (Anova) satu jalur. Menurut Warner (2008, p.215), uji Anova atau Anava digunakan dalam suatu penelitian yang mana peneliti akan membandingkan data antara dua variabel atau lebih. Dalam penelitian ini, terdapat tiga variabel yang akan dibandingkan dengan menggunakan perhitungan statistik tersebut yaitu media poster, media mind mapping serta pembelajaran tanpa menggunakan media. Semua perhitungan tersebut menggunakan SPSS 17. Untuk mengetahui seberapa jauh perbedaan dan mana yang lebih efektif antara ketiga teknik pembelajaran tersebut dilakukan uji Scheffe.

\section{HASIL DAN PEMBAHASAN}

Data yang berupa penilaian tentang keterampilan berpidato siswa SMK diperoleh dengan menggunakan instrumen lembar penilaian performansi keterampilan berpidato. Pengamatan dan penilaian performansi keterampilan dilaksanakan dua kali yaitu sebelum (pretest) dan sesudah (posttest) pelaksanaan pembelajaran keterampilan berpidato untuk siswa SMK. Pretes dilaksanakan pada tanggal 24 Juli 2012 untuk kelas eksperimen 1 dan eksperimen 2, serta tanggal 26 Juli 2012 untuk kelas kontrol.

Materi yang diujikan dalam pretest tersebut yaitu keterampilan berpidato siswa di depan kelas dengan tema pilihan bebas, antara lain yaitu kesehatan, pendidikan, lingkungan, sosial, seni budaya, politik serta keagamaan. Adapun hasil pretes keterampilan berpidato siswa dapat diihat dari Tabel 1 berikut ini.

Tabel 1. Pretes Keterampilan Berpidato

\begin{tabular}{cccc}
\hline & $\begin{array}{c}\text { Kelas } \\
\text { Kontrol }\end{array}$ & $\begin{array}{c}\text { Kelas } \\
\text { Eksperimen } \\
\mathbf{1}\end{array}$ & $\begin{array}{c}\text { Kelas } \\
\text { Eksperimen } \\
\mathbf{2}\end{array}$ \\
\hline $\mathrm{N}$ & 20 & 20 & 20 \\
$\sum \mathrm{X}$ & 1353 & 1356 & 1363 \\
$\overline{\mathrm{X}}$ & 67,65 & 67,80 & 68,15 \\
$\sum \mathrm{X}^{2}$ & 91857 & 92304 & 93175 \\
$\mathrm{SD}$ & 4,146 & 4,396 & 3,884 \\
\hline
\end{tabular}

\section{Deskripsi Kemampuan Awal}

Kelas Kontrol

Peserta didik kelas kontrol yaitu peserta didik kelas X Otomotif B SMK Diponegoro Depok, Sleman yang berjumlah 20 siswa. Oleh karena statusnya sebagai kelompok kontrol, maka pembelajaran berpidato dilaksanakan tanpa menggunakan media selama enam kali pertemuan.

Tabel 2. Distribusi Frekuensi Nilai Pretes Kelas Kontrol

\begin{tabular}{ccc}
\hline Nilai & Frekuensi \\
\hline $74-76$ & 1 \\
$71-73$ & 3 \\
$68-70$ & 5 \\
$65-67$ & 5 \\
$62-64$ & 6 \\
$\mathrm{~N}$ & 20 \\
\hline
\end{tabular}

Frekuensi

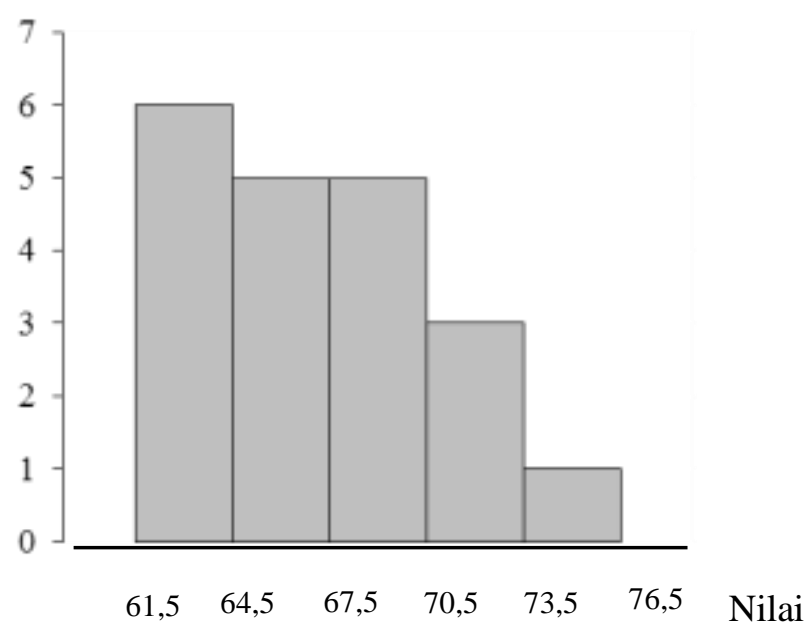

Gambar 1. Histogram Nilai Keterampilan Berpidato Hasil Pretes Kelas Kontrol

Berdasarkan histogram hasil pretes kelas kontrol tersebut terlihat bahwa siswa yang me- 
miliki nilai antara 62-64 sebanyak 6 orang, antara 65-67 sebanyak 5 orang, antara 68-70 sebanyak 5 orang, antara 71-73 sebanyak 3 orang, dan antara 74-76 sebanyak 1 orang. Dengan demikian, dari total 20 siswa pada kelas kontrol, rentang nilai terendah yaitu antara 6264 dimiliki oleh paling banyak siswa, yaitu dengan jumlah 6 siswa. Rentang nilai tertinggi, yaitu antara 74-76 paling sedikit dimiliki oleh siswa yaitu hanya 1 orang.

\section{Kelas Eksperimen 1}

Peserta didik kelas eksperimen 1 yaitu peserta didik kelas X Otomotif A SMK Diponegoro Depok, Sleman sebanyak 20 siswa. Pembelajaran keterampilan berpidato dilaksanakan dengan menggunakan media mind mapping atau peta konsep.

Tabel 3. Distribusi Frekuensi Pretes Kelas Eksperimen 1

\begin{tabular}{cc}
\hline Nilai & Frekuensi \\
\hline $74-76$ & 2 \\
$71-73$ & 2 \\
$68-70$ & 5 \\
$65-67$ & 5 \\
$62-64$ & 6 \\
$\mathrm{~N}$ & 20 \\
\hline
\end{tabular}

Frekuensi

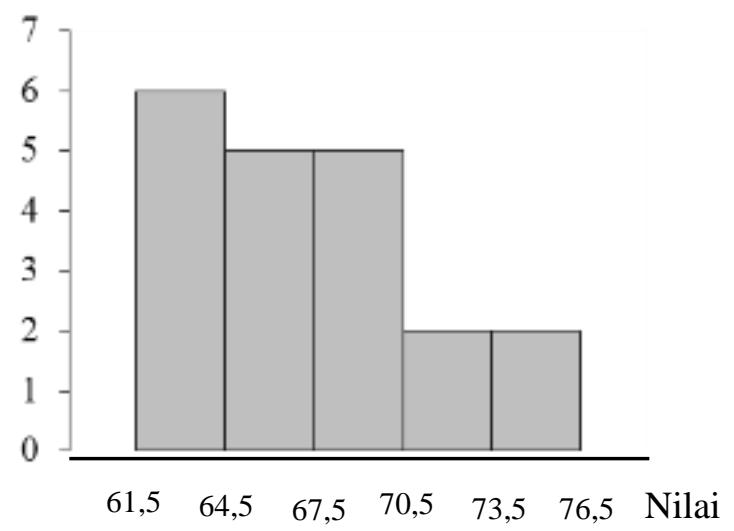

Gambar 2. Histogram Nilai Keterampilan Berpidato Hasil Pretes Kelas Eksperimen 1

Berdasarkan histogram hasil pretes ke las eksperimen $1 \mathrm{di}$ atas terlihat bahwa siswa yang memiliki nilai antara 62-64 sebanyak 6 orang, antara 65-67 sebanyak 5 orang, antara 68-70 sebanyak 5 orang, antara 71-73 sebanyak 2 orang, dan antara 74-76 sebanyak 2 orang. Dengan demikian, dari total 20 siswa pada kelas eksperimen 1 , rentang nilai terendah yaitu antara 62-64 dimiliki oleh paling banyak siswa, yaitu dengan jumlah 6 siswa. Rentang nilai tertinggi, yaitu antara 74-76 hanya dimiliki oleh 2 siswa.

\section{Kelas Eksperimen 2}

Peserta didik kelas eksperimen 2 yaitu peserta didik kelas X Otomotif C SMK Diponegoro Depok, Sleman sebanyak 20 siswa. Pembelajaran keterampilan berpidato dilaksanakan dengan menggunakan media poster.

Tabel 4. Distribusi Frekuensi Pretes Kelas Eksperimen 2

\begin{tabular}{cc}
\hline Nilai & Frekuensi \\
\hline $74-76$ & 1 \\
$71-73$ & 3 \\
$68-70$ & 6 \\
$65-67$ & 6 \\
$62-64$ & 4 \\
$\mathrm{~N}$ & 20 \\
\hline
\end{tabular}

\section{Frekuensi}

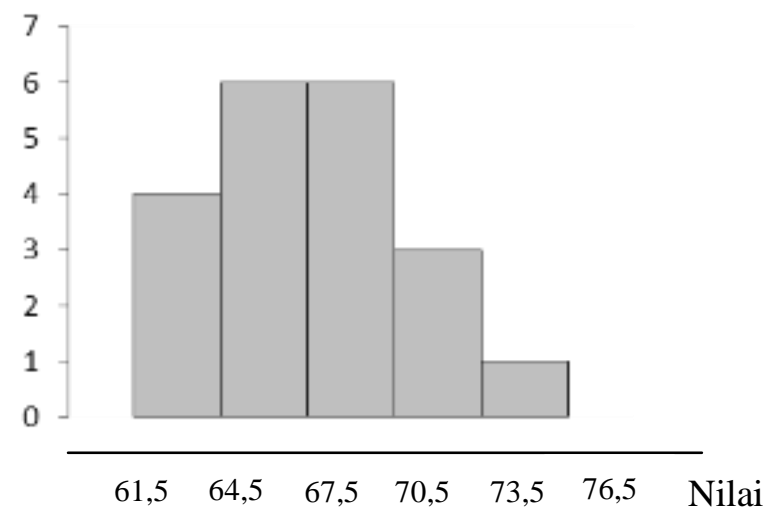

Gambar 3. Histogram Nilal Keterampilan Berpidato Hasil Pretes Kelas Eksperimen 2

Berdasarkan histogram hasil pretes kelas eksperimen 2 di atas terlihat bahwa siswa yang memiliki nilai antara 62-64 sebanyak 4 orang, antara 65-67 sebanyak 6 orang, antara 68-70 sebanyak 6 orang, antara 71-73 sebanyak 3 orang, dan antara 74-76 sebanyak 1 orang. Dengan demikian, dari total 20 siswa pada kelas eksperimen 2, rentang nilai yang ter-banyak dimiliki siswa yaitu antara 65-67 sebanyak 6 orang serta 68-70 sebanyak 6 orang. Rentang nilai tertinggi, yaitu antara 74-76 paling sedikit dimiliki oleh siswa yaitu hanya 1 orang, sedangkan rentang nilai terendah yaitu antara 62-64 dimiliki oleh 4 siswa.

\section{Deskripsi Kemampuan Akhir}

Postes dilaksanakan setelah eksperimen, deskripsi hasil penilaian postes keterampilan berpidato dapat dilihat pada Tabel 5 di berikut ini. 
Tabel 5. Postes Keterampilan Berpidato

\begin{tabular}{cccc}
\hline & $\begin{array}{c}\text { Kelas } \\
\text { Kontrol }\end{array}$ & $\begin{array}{c}\text { Kelas } \\
\text { Eksperimen 1 }\end{array}$ & $\begin{array}{c}\text { Kelas } \\
\text { Eksperimen 2 }\end{array}$ \\
\hline $\mathrm{N}$ & 20 & 20 & 20 \\
$\sum \mathrm{X}$ & 1392 & 1547 & 1479 \\
$\mathrm{X}$ & 69.60 & 77.35 & 73.95 \\
$\sum \mathrm{X}^{2}$ & 97298 & 119999 & 109573 \\
$\mathrm{SD}$ & 4.672 & 4.221 & 3.252 \\
\hline
\end{tabular}

\section{Kelas Kontrol}

Tabel 6. Distribusi Frekuensi Postes Kelas Kontrol

\begin{tabular}{cc}
\hline Nilai & Frekuensi \\
\hline $80-82$ & 1 \\
$77-79$ & 0 \\
$74-76$ & 2 \\
$71-73$ & 4 \\
$68-70$ & 4 \\
$65-67$ & 1 \\
$62-64$ & 2 \\
$\mathrm{~N}$ & 20 \\
\hline
\end{tabular}

\section{Frekuensi}

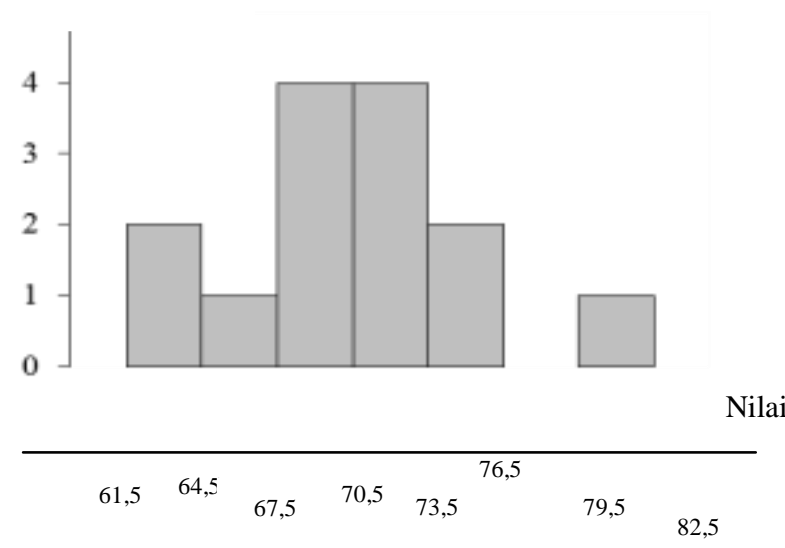

Gambar 4. Histogram Nilai Keterampilan Berpidato Hasil Postes Kelas Kontrol

Berdasarkan histogram hasil postes ke-las kontrol tersebut terlihat bahwa siswa yang memiliki nilai antara 62-64 sebanyak 2 orang, antara 65-67 sebanyak 1 orang, antara 68-70 sebanyak 4 orang, antara 71-73 sebanyak 4 orang, antara 74-76 sebanyak 2 orang, antara 8082 hanya 1 orang, serta tidak ada siswa yang memiliki rentang nilai antara 77-79. Dengan demikian, dari total 20 siswa pada kelas kontrol, rentang nilai yang terbanyak dimiliki siswa yaitu antara 68-70 sebanyak 4 orang serta $71-73$ sebanyak 4 orang. Rentang nilai tertinggi, yaitu antara 80-82 hanya dimiliki oleh 1 orang, sedangkan rentang nilai terendah dimiliki oleh 2 siswa.

Kelas Eksperimen 1

Tabel 7. Distribusi Frekuensi Postest Kelas Eksperimen 1

\begin{tabular}{cc}
\hline Nilai & Frekuensi \\
\hline $84-86$ & 2 \\
$81-83$ & 2 \\
$78-80$ & 2 \\
$75-77$ & 9 \\
$72-74$ & 5 \\
\hline $\mathrm{N}$ & 20 \\
\hline
\end{tabular}

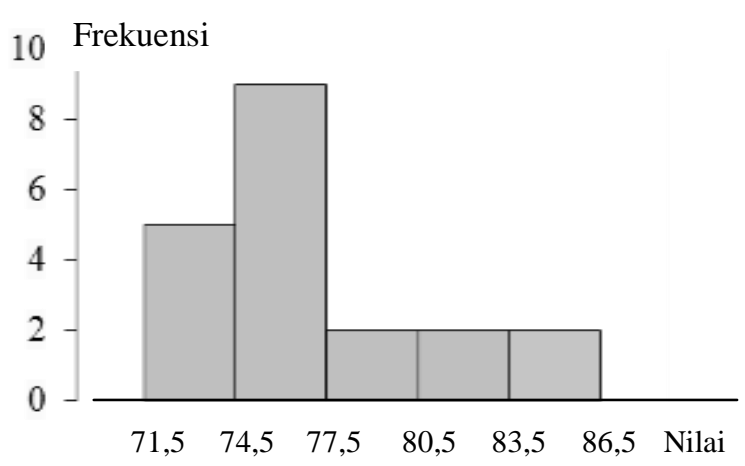

Gambar 5. Histogram Nilai Keterampilan Berpidato Hasil Postes Kelas Eksperimen 1

Berdasarkan histogram hasil postes ke-las eksperimen 1 di atas terlihat bahwa siswa yang memiliki nilai antara 72-74 sebanyak 5 orang, antara 75-77 sebanyak 9 orang, antara 78-80 sebanyak 2 orang, antara 81-83 sebanyak 2 orang, serta antara 84-86 sebanyak 2 orang. Dengan demikian, dari total 20 siswa pada kelas eksperimen 1 , rentang nilai yang terbanyak dimiliki siswa yaitu antara 75-77 sebanyak 9. Rentang nilai tertinggi, yaitu antara 84-86 dimiliki oleh 2 orang siswa, sedangkan rentang nilai terendah yaitu antara 72-75 dimiliki oleh 5 siswa. 
Kelas Eksperimen 2

Tabel 8. Distribusi Frekuensi Postes Kelas Eksperimen 2

\begin{tabular}{cc}
\hline Nilai & Frekuensi \\
\hline $80-82$ & 2 \\
$77-79$ & 0 \\
$74-76$ & 6 \\
$71-73$ & 9 \\
$68-70$ & 2 \\
$65-67$ & 1 \\
$\mathrm{~N}$ & 20 \\
\hline
\end{tabular}

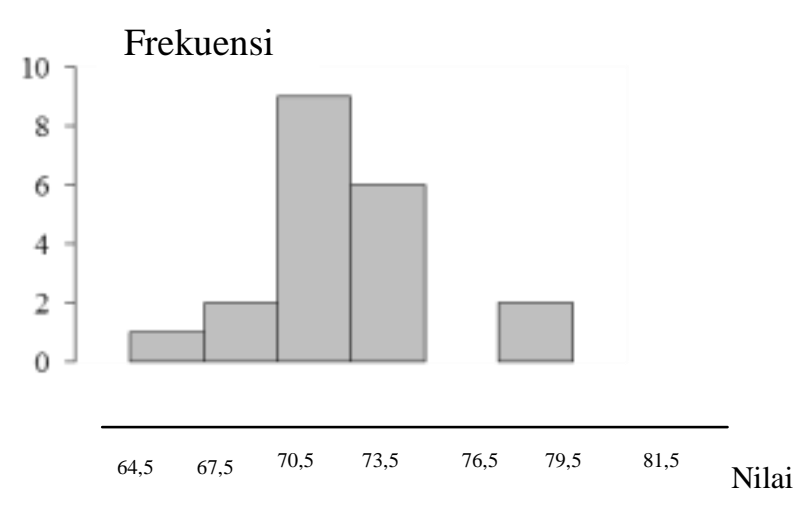

Gambar 6. Histogram Nilai Keterampilan Berpidato Hasil Postes Kelas Eksperimen 2

Berdasarkan histogram hasil postes ke-las eksperimen 2 di atas terlihat bahwa siswa yang memiliki nilai antara 65-67 sebanyak 1 orang, antara 68-70 sebanyak 2 orang, antara 71-73 sebanyak 9 orang, antara 74-76 sebanyak 6 orang, antara 80-82 sebanyak 2 orang, serta tidak seorang pun siswa yang memiliki rentang nilai antara 77-79. Dengan demikian, dari total 20 siswa pada kelas eksperimen 2, rentang nilai yang terbanyak dimiliki siswa yaitu antara 71-77 sebanyak 9. Rentang nilai tertinggi, yaitu antara 80-82 dimiliki oleh 2 orang siswa, sedangkan rentang nilai terendah hanya dimiliki oleh 1 orang siswa.

\section{Pengujian Hipotesis}

Apabila pengujian asumsi normalitas sebaran dan homogenitas varian telah terpenuhi, maka persyaratan parametrik uji hipotesis menggunakan Anova yang dilanjutkan dengan uji Scheffe dapat dilaksanakan. Uji perbedaan nilai kemampuan berpidato antara kelas kontrol dengan kelas eksperimen dalam penelitian ini, baik pretes maupun postes digunakan Anava satu jalur. Hipotesis yang diuji yaitu sebagai berikut. Pertama, ada perbedaan signifikan dalam keterampilan berpidato antara kelompok eksperimen 1 yang pembelajarannya menggunakan media mind mapping atau peta konsep dengan kelompok kontrol yang pembelajarannya tanpa menggunakan media dalam pembelajaran berpidato. Kedua, ada perbedaan signifikan dalam keterampilan berpidato antara kelompok eksperimen 2 yang pembelajarannya menggunakan media poster dengan kelompok kontrol yang pembelajarannya tanpa menggunakan media dalam pembelajaran berpidato. Ketiga, ada perbedaan signifikan dalam keterampilan berpidato antara kelompok eksperimen 1 yang pembelajarannya menggunakan media peta konsep atau mind mapping dengan kelompok eksperimen 2 yang pembelajarannya menggunakan media poster.

Pada pengujian Hipotesis pertama, kedua serta ketiga ringkasan hasil perhitungan postes anava satu jalur yang dilanjutkan dengan uji Scheffe dengan program SPSS 17 disajikan pada Tabel 9 sebagai berikut.

Tabel 9. Ringkasan Hasil Perhitungan Postes dengan Anava Satu Jalur

\begin{tabular}{lccccc}
\hline & $\begin{array}{c}\text { Jumlah } \\
\text { Kuadrat }\end{array}$ & df & $\begin{array}{c}\text { Rata-rata } \\
\text { Kuadrat }\end{array}$ & F & Sig. \\
\hline Antara & 603.633 & 2 & 301.817 & 18.027 & .000 \\
Grup & & & & & \\
$\begin{array}{l}\text { Dalam } \\
\text { Group }\end{array}$ & 954.300 & 57 & 16.742 & & \\
Jumlah & 1557.933 & 59 & & & \\
\hline
\end{tabular}

Secara keseluruhan hasil perhitungan Anava satu jalur tentang proses pembelajaran yang paling efektif antara penggunaan media mind mapping atau peta konsep, penggunaan media poster dengan tanpa menggunakan media dalam pembelajaran keterampilan berpida-to untuk siswa SMK, menghasilkan F hitung sebesar 18,027. Nilai Fhitung kemudian dikonfirmasikan dengan $\mathrm{F}$ tabel dengan taraf signifikansi $0,05(5 \%)$, dk 2 untuk pembilang dan 57 untuk penyebut, diperoleh angka sebesar 3,16 yang berarti lebih kecil dari Fhitung $(18,027)$, serta peluang kesalahan lebih kecil dari signifikansi yang ditetapkan $(0,000<0,05)$. Dengan demikian, dapat disimpulkan bahwa ada perbedaan yang signifikan antara penggunaan media mind mapping atau peta konsep, penggunaan media poster dengan tanpa menggunakan media dalam pembelajaran keterampilan berpidato untuk siswa SMK. Selanjutnya, untuk mengetahui mana yang lebih efektif dari ketiga proses pembelajaran tersebut, maka dilanjutkan dengan uji Scheffe yang hasilnya terdapat pada Tabel 10 berikut ini. 
Tabel 10. Ringkasan Hasil Uji Scheffe Posttest

(I) Perlakuan (J) Perlakuan Mean Difference (I-J) Std. Error Sig.

\begin{tabular}{llccccc}
\hline Kontrol & Eksperimen 1 & $-7.750^{*}$ & 1.294 & .000 & -11.00 & -4.50 \\
& Eksperimen 2 & $-4.350^{*}$ & 1.294 & .046 & -7.60 & -1.10 \\
Eksperimen 1 & Kontrol & $7.750^{*}$ & 1.294 & .000 & 4.50 & 11.00 \\
& Eksperimen 2 & $3.400^{*}$ & 1.294 & .038 & .15 & 6.65 \\
\multirow{2}{*}{ Eksperimen 2 } & Kontrol & $4.350^{*}$ & 1.294 & .046 & 1.10 & 7.60 \\
& Eksperimen 1 & $-3.400^{*}$ & 1.294 & .038 & -6.65 & -.15 \\
\hline
\end{tabular}

\section{Uji Hipotesis Pertama}

Uji hipotesis yang pertama adalah "ada perbedaan signifikan dalam keterampilan berpidato antara kelompok eksperimen 1 yang pembelajarannya menggunakan media mind mapping atau peta konsep dengan kelompok kontrol yang pembelajarannya tanpa menggunakan media dalam pembelajaran berpidato". Kriteria pengujian adalah Ho diterima jika nilai signifikansi (sig) lebih besar dari alpha 5\% $(0,05)$, dan Ho ditolak jika nilai signifikansi ( $s i g$ ) lebih kecil dari alpha $5 \%(0,05)$.

Berdasarkan Tabel 10, secara keseluruhan hasil perhitungan dengan uji Scheffe tentang adanya perbedaan signifikan dalam keterampilan berpidato antara kelompok eksperimen 1 yang pembelajarannya menggunakan media poster dengan kelompok kontrol yang pembelajarannya tanpa menggunakan media dalam pembelajaran berpidato diperoleh probabilitas sebesar 0,000, lebih kecil dari 0,05, maka $\mathrm{H}_{\mathrm{o}}$ ditolak dan $\mathrm{H}_{\mathrm{a}}$ diterima. Simpulan dari pengujian ini adalah bahwa terdapat perbedaan signifikan antara kelompok eksperimen 1 yang pembelajarannya menggunakan media mind mapping atau peta konsep dengan kelompok kontrol yang pembelajarannya tanpa menggunakan media dalam pembelajaran keterampilan berpidato untuk siswa SMK.

Untuk menentukan apakah media mind mapping lebih efektif maka perlu melihat Tabel 10 tentang perbandingan batas atas dan batas bawah kelas eksperimen 1 dengan kelas kontrol. Apabila batas atas dan batas bawah kelas eksperimen 1 terhadap kelas kontrol lebih besar dari batas atas dan batas bawah kelas kontrol terhadap kelas eksperimen 1, maka dapat disimpulkan bahwa media mind mapping lebih efektif dibandingkan dengan pembelajaran konvensional. Batas bawah konfidensi kelas eksperimen 1 terhadap kelas kontrol bernilai positif sebesar
4,50 dan batas atas bernilai positif sebesar 11,00 , sedangkan batas bawah dan batas atas konfidensi kelas kontrol terhadap kelas eksperimen 1 bernilai negatif yaitu $-11,00$ dan $-4,50$. Dapat disimpulkan bahwa batas atas dan batas bawah kelas eksperimen 1 terhadap kelas kontrol lebih besar dari batas atas dan batas bawah kelas kontrol terhadap kelas eksperimen 1. Dengan demikian, pembelajaran keterampilan berpidato yang menggunakan media mind mapping atau peta konsep lebih efektif dibandingkan dengan pembelajaran keterampilan berpidato tanpa menggunakan media.

\section{Uji Hipotesis Kedua}

Uji hipotesis yang kedua adalah "Ada perbedaan signifikan dalam keterampilan berpidato antara kelompok eksperimen 2 yang pembelajarannya menggunakan media poster dengan kelompok kontrol yang pembelajarannya tanpa menggunakan media dalam pembelajaran berpidato". Kriteria pengujian adalah Ho diterima jika nilai signifikansi (sig) lebih besar dari alpha $5 \%$ (0.05), dan Ho ditolak jika nilai signifikansi (sig) lebih kecil dari alpha 5\% (0.05).

Berdasarkan Tabel 10, secara keseluruhan hasil perhitungan dengan uji Scheffe tentang adanya perbedaan signifikan dalam keterampilan berpidato antara kelompok eksperimen 2 yang pembelajarannya menggunakan media poster dengan kelompok kontrol yang pembelajarannya tanpa menggunakan media dalam pembelajaran berpidato diperoleh probabilitas sebesar 0,046 , lebih besar dari 0,05 , maka $\mathrm{H}_{\mathrm{o}}$ diterima dan $\mathrm{H}_{\mathrm{a}}$ ditolak. Simpulan dari pengujian ini adalah bahwa terdapat perbedaan signifikan antara kelompok eksperimen 2 yang pembelajarannya menggunakan media poster dengan kelompok kontrol yang pembelajarannya tanpa menggunakan media dalam pembelajaran keterampilan berpidato untuk siswa SMK. 
Untuk menentukan apakah media pos-ter lebih efektif maka perlu melihat Tabel 10 tentang perbandingan batas atas dan batas bawah konfidensi kelas eksperimen 2 dengan kelas kontrol. Apabila batas atas dan batas bawah kelas eksperimen 2 terhadap kelas kontrol lebih besar dari pada batas atas dan batas bawah kelas kontrol terhadap kelas eksperimen 2, maka dapat disimpulkan bahwa media poster lebih efektif daripada pembelajaran tanpa media.

Batas bawah konfidensi kelas eksperimen 2 terhadap kelas kontrol bernilai positif sebesar 1,10 dan batas atas bernilai positif sebesar 7,60, sedangkan batas bawah dan batas atas konfidensi kelas kontrol terhadap kelas eksperimen 2 bernilai negatif yaitu $-7,60$ dan -1,10. Dapat disimpulkan bahwa batas atas dan batas bawah kelas eksperimen 2 terhadap kelas kontrol lebih besar dari batas atas dan batas bawah kelas kontrol terhadap kelas eksperimen 2. Dengan demikian, dapat disimpulkan bahwa pembelajaran keterampilan berpidato menggunakan media poster lebih efektif dibandingkan dengan pembelajaran keterampilan berpidato tanpa menggunakan media.

\section{Uji Hipotesis Ketiga}

Uji hipotesis yang ketiga adalah "Ada perbedaan signifikan dalam keterampilan berpidato antara kelompok eksperimen 1 yang pembelajarannya menggunakan media peta konsep atau mind mapping dengan kelompok eksperimen 2 yang pembelajarannya menggunakan media poster". Kriteria pengujian adalah Ho diterima jika nilai signifikansi ( $\mathrm{sig}$ ) lebih besar dari alpha 5\% (0.05), dan Ho ditolak jika nilai signifikansi (sig) lebih kecil dari alpha 5\% (0.05).

Berdasarkan Tabel 10, secara keseluruhan hasil perhitungan dengan uji Scheffe tentang adanya perbedaan signifikan dalam keterampilan berpidato antara kelompok eksperimen 1 yang pembelajarannya menggunakan media peta konsep atau mind mapping dengan kelompok eksperimen 2 yang pembelajarannya menggunakan media poster dalam pembelajaran berpidato diperoleh probabilitas sebesar 0,038 , lebih kecil dari 0,05 , maka $\mathrm{H}_{\mathrm{o}}$ ditolak dan $\mathrm{H}_{\mathrm{a}}$ diterima. Simpulan dari pengujian ini adalah bahwa terdapat perbedaan signifikan antara kelompok eksperimen 1 yang pembelajarannya menggunakan media peta konsep atau mind mapping dengan kelompok eksperimen 2 yang pembelajarannya menggunakan media poster dalam pembelajaran keterampilan berpidato untuk siswa SMK.
Untuk menentukan media yang lebih efektif maka perlu melihat Tabel 10 tentang perbandingan batas atas dan batas bawah konfidensi kelas eksperimen 1 dengan kelas eksperimen 2. Apabila batas atas dan batas bawah kelas eksperimen 1 terhadap kelas eksperimen 2 lebih besar dari pada batas atas dan batas bawah kelas eksperimen 2 terhadap kelas eksperimen 1, maka dapat disimpulkan bahwa media mind mapping lebih efektif daripada media poster. Sebaliknya, apabila batas atas dan batas bawah kelas eksperimen 2 terhadap kelas eksperimen 1 lebih besar dari pada batas atas dan batas bawah kelas kelas eksperimen 1 terhadap kelas eksperimen 2, maka dapat disimpulkan bahwa media poster lebih efektif daripada media mind mapping.

Batas bawah konfidensi kelas eksperimen 1 bernilai positif sebesar 0,15 dan batas atas bernilai positif sebesar 6,65 , sedangkan batas bawah konfidensi kelas eksperimen 2 bernilai negatif $-6,65$ dan batas atas bernilai negatif 0,15 . Dapat disimpulkan bahwa batas atas dan batas bawah kelas eksperimen 1 terhadap kelas eksperimen 2 lebih besar dari batas atas dan batas bawah kelas eksperimen 2 terhadap kelas eksperimen 2. Dengan demikian, dapat disimpulkan bahwa pembelajaran keterampilan berpidato dengan menggunakan media mind mapping atau peta konsep lebih efektif dibandingkan dengan pembelajaran keterampilan berpidato menggunakan media poster.

\section{Pembahasan Hasil Penelitian}

Pada bagian ini diuraikan pembahasan terhadap hasil-hasil penelitian yang meliputi: (1) media mind mapping efektif digunakan dalam pembelajaran keterampilan berpidato untuk siswa SMK, (2) media poster efektif digunakan dalam pembelajaran keterampilan berpidato untuk siswa SMK, serta (3) media yang paling efektif antara media mind mapping dengan media poster dalam pembelajaran keterampilan berpidato untuk siswa SMK.

Media Mind Mapping Efektif Digunakan dalam Pembelajaran Keterampilan Berpidato untuk Siswa SMK

Mind mapping (peta konsep) merupakan salah satu metode yang membantu memudahkan siswa untuk berpikir secara teratur dan terkonsep dalam belajar. Selanjutnya, mind mapping (peta konsep) bisa diwujudkan menjadi sebuah media pembelajaran dalam pembelajaran berpidato yang mudah dibuat. Dalam media tersebut 
terdapat ilustrasi grafis konkret yang berupa gambar serta tulisan dua dimensi untuk mempresentasikan konsep-konsep secara teratur dengan cara menghubungkan garis-garis penghubung antar konsep-konsep tersebut. Hal tersebut, sesuai dengan teori bahwa pidato yang baik adalah pidato yang terkonsep.

Berdasarkan uraian di atas, penggunaan mind mapping atau peta konsep sebagai media pembelajaran berpidato dapat membantu siswa untuk mengkonsep ide-ide kreatif mereka dan membantu siswa dalam berpidato secara runtut, lengkap dan jelas. Selanjutnya, seberapa efektifkah media mind mapping (peta konsep) apabila digunakan dalam pembelajaran berpidato dibandingkan dengan pembelajaran konvensional atau tanpa media pembelajaran akan diuraikan sebagai berikut.

Hasil uji Scheffe tentang keefektifan antara penggunaan media mind mapping atau peta konsep dengan tanpa menggunakan media dalam pembelajaran keterampilan berpidato siswa SMK menunjukkan probabilitas sebesar 0,000 lebih kecil dari 0,05. Berdasarkan hal tersebut, maka Ho yang menyatakan bahwa tidak ada perbedaan sigifikan antara penggunaan media mind mapping atau peta konsep dengan tanpa menggunakan media dalam pembelajaran keterampilan berpidato siswa SMK ditolak dan Ha yang menyatakan bahwa ada perbedaan signifikan antara penggunaan media mind mapping atau peta konsep dengan tanpa menggunakan media dalam pembelajaran keterampilan berpidato siswa SMK diterima.

Batas bawah konfidensi kelas eksperimen 1 (media mind mapping atau peta konsep) terhadap kelas kontrol bernilai positif sebesar 4,50 dan batas atas bernilai positif sebesar 11,00 , sedangkan batas bawah dan batas atas konfidensi kelas kontrol (tanpa menggunakan media) terhadap kelas eksperimen 1 bernilai negatif yaitu $-11,00$ dan -4,50. Berdasarkan uraian di atas, dapat disimpulkan bahwa pembelajaran keterampilan berpidato menggunakan media mind mapping atau peta konsep lebih efektif dibandingkan dengan pembelajaran keterampilan berpidato tanpa menggunakan media.

Media Poster Efektif Digunakan dalam Pembelajaran Keterampilan Berpidato untuk Siswa SMK

Poster merupakan kombinasi visual dengan warna dan pesan dengan maksud untuk menangkap perhatian orang yang lewat, tetapi cukup lama menanamkan suatu pesan dan gagasan yang berarti di dalam ingatan orang yang melihatnya. Komposisi, warna, dan teknik adalah unsur pokok dalam penyajian poster. Imajinasi kreatif, ditambah dengan pemusatan perhatian yang bagus diharapkan mampu membantu siswa untuk penyampaian gagasan yang efektif dan kreatif dalam berpidato. Dengan demikian, penggunaan media poster dapat memotivasi siswa dalam mengikuti proses pembelajaran keterampilan berpidato di kelas serta dapat meningkatkan keterampilan siswa dalam berpidato. Selanjutnya, seberapa efektifkah media poster apabila digunakan dalam pembelajaran berpidato dibandingkan dengan pembelajaran konvensional atau tanpa media pembelajaran akan diuraikan sebagai berikut.

Hasil uji Scheffe tentang keefektifan antara penggunaan media poster dengan tanpa menggunakan media dalam pembelajaran keterampilan berpidato siswa SMK menunjukkan probabilitas sebesar 0,06 lebih besar dari 0,05. Berdasarkan hal tersebut, maka Ho yang menyatakan bahwa tidak ada perbedaan yang signifikan antara penggunaan media poster dengan tanpa menggunakan media dalam pembelajaran keterampilan berpidato siswa SMK ditolak dan Ha yang menyatakan bahwa ada perbedaan yang signifikan antara penggunaan media poster dengan tanpa menggunakan media dalam pembelajaran keterampilan berpidato siswa SMK diterima.

Batas bawah konfidensi kelas eksperimen 2 (media poster) terhadap kelas kontrol bernilai positif sebesar 1,10 dan batas atas bernilai positif sebesar 7,60, sedangkan batas bawah dan batas atas konfidensi kelas kontrol (tanpa menggunakan media) terhadap kelas eksperimen 2 bernilai negatif yaitu $-7,60$ dan $-1,10$. Berdasarkan uraian tersebut, dapat disimpulkan bahwa pembelajaran keterampilan berpidato menggunakan media poster lebih efektif dibandingkan dengan pembelajaran keterampilan berpidato tanpa menggunakan media.

Media yang Paling Efektif antara Media Mind Mapping dengan Media Poster dalam Pembelajaran Keterampilan Berpidato untuk Siswa SMK

Penggunaan media mind mapping (peta konsep) dalam pembelajaran berpidato dapat membantu siswa untuk menyampaikan gagasan berpidatonya secara runtut, lengkap dan jelas, sedangkan penggunaan media poster dalam pembelajaran berpidato dapat membantu siswa 
dalam berpidato secara efektif dan kreatif. Dari kedua media tersebut, media manakah yang paling efektif apabila digunakan dalam pembelajaran berpidato akan dibahas pada uraian di bawah ini.

Hasil uji Scheffe tentang keefektifan antara penggunaan media peta konsep atau mind mapping dengan penggunaan media poster dalam pembelajaran berpidato untuk siswa SMK diperoleh probabilitas sebesar 0,038. Berdasarkan hal tersebut, maka $\mathrm{H}_{\mathrm{o}}$ yang menyatakan bahwa tidak ada perbedaan yang signifikan antara penggunaan media mind mapping atau peta konsep dengan penggunaan media poster dalam pembelajaran berpidato untuk siswa SMK ditolak dan $\mathrm{H}_{\mathrm{a}}$ yang menyatakan bahwa ada perbedaan yang signifikan antara penggunaan media peta konsep atau mind mapping dengan penggunaan media poster dalam pembelajaran berpidato untuk siswa SMK diterima.

Batas bawah konfidensi kelas eksperimen 1 (media mind mapping atau peta konsep) terhadap kelas eksperimen 2 bernilai positif sebesar 0,15 dan batas atas bernilai positif sebesar 6,65, sedangkan batas bawah konfidensi kelas eksperimen 2 (media poster) terhadap kelas eksperimen 1 bernilai $-6,65$ dan batas atas bernilai $-0,15$. Berdasarkan uraian tersebut, dapat disimpulkan bahwa pembelajaran keterampilan berpidato dengan menggunakan media mind mapping atau peta konsep lebih efektif dibandingkan dengan pembelajaran keterampilan berpidato menggunakan media poster.

\section{SIMPULAN}

Pembelajaran keterampilan berpidato siswa SMK menggunakan media mind mapping atau peta konsep lebih efektif dibandingkan dengan tanpa menggunakan media. Pembelajaran keterampilan berpidato siswa SMK menggunakan media poster lebih efektif dibandingkan dengan tanpa menggunakan media. Pembelajaran keterampilan berpidato siswa SMK dengan menggunakan media mind mapping atau peta konsep lebih efektif dibandingkan dengan menggunakan media poster. Dengan demikian, mind mapping atau peta konsep merupakan media yang paling efektif dibandingkan dengan media poster dan pembelajaran tanpa media dalam pembelajaran keterampilan berpidato siswa SMK.

\section{DAFTAR PUSTAKA}

Rivai, A \& Sudjana, N. (2002). Media pembelajaran. Bandung: Sinar Baru Algesindo.

Buzan, T. (2008). Buku pintar mind map. Jakarta: PT Gramedia Pustaka Utama.

Brown, H.D. (2004). Language assesment: Principles and classroom practice. New York: Longman.

Hadinegoro, L. (2007). Teknik seni berpidato mutakhir. Yogyakarta: Absolut.

Oka, I Gusti Ngurah. (1976). Retorik. Bandung: Terate.

Warner, R.M. (2008). Applied Statistick. United States of America: Sage Publications, Inc 